\title{
Serum and Platelet Lipoamide Dehydrogenase in Friedreich's Ataxia
}

\author{
A. FILLA, R. F. BUTTERWORTH, G.: GEOFFROY, B. LEMIEUX, AND A. BARBEAU
}

\begin{abstract}
SUMMARY: Pyruvate dehydrogenase $(P D H), \alpha-k e t o$ glat arate dehydrogenase $(\alpha \cdot K G D H)$ and lipoamide dehydrogenase ( $L A D)$ were measured in platelets of 11 patients with typical Friedreich's ataxia and 10 normal control subjects. Serum $L A D$ was also evaluated in the same patients. No statistically significant changes were found in platelets for the group as a whole, although some patients had low values (more than one standard deviation below control mean). Serum LAD was significantly reduced in the patients with Friedreich's ataxia. This was not due to associated diabetes.
\end{abstract}

RÉSUMÉ: La pyruvate dehydrogenase $(P D H)$, la dehydrogenase de l'acide $\alpha$-ketoglutarique $(\alpha-K G D H)$ et la lipoamide dehydrogenase ( $L A D)$ furent mesurés dans les plaquettes de II patients avec ataxie de Friedreich typique et de 10 sujets contrôles normaux. Nous n'avons trouvé aucune diminution significative dans les plaquettes lorsque le groupe est considéré dans son entier, mais certains patients montraient des valeurs basses (plus d'une erreur type sous la moyenne des contrôles). Le LAD sérique, par contre, était significativement diminué chez les patients souffrant d'ataxie de Friedreich. Ceci n'est pas dû à un diabète associé.

\footnotetext{
From the Department of Neurobiology, Clinical Research Institute of Montreal; Hôpital SainteJustine, Montreal; and Centre Hospitalier Universitaire de Sherbrooke.

Reprint requests for the complete supplement on Friedreich's ataxia (Phase Two, Part One) to: Dr. André Barbeau, Clinical Research Institute of Montreal, 110 Pine Avenue West, Montreal, Quebec, Canada H2W IR7.
}

\section{INTRODUCTION}

Many studies have indicated that pyruvate oxidation is impaired in diseases showing evidence of ataxia and peripheral neuropathy. Blass and his co-workers (Kark et al., 1974; Blass et al., 1976) have found decreases in the activity of pyruvate dehydrogenase (PDH) and $\alpha$-ketoglutarate dehydrogenase $(\alpha-K G D H)$ in muscle and fibroblasts of patients with spinocerebeldegnerations, and postulated that the defect was situated at the level of the $E_{3}$ component of PDH. In previous studies in Friedreich's ataxia, Barbeau et al. (1976) could not confirm this finding. Only a small percentage (less than $30 \%$ ) of patients with typical Friedreich's ataxia were found to show a defect in pyruvate oxidation, with low PDH activity in fibroblasts. In all studies performed by us, the first two components of the PDH complex ( $E_{1}$ and $E_{2}$ ) were normal, but a $29 \%$ decrease was found in the $E_{3}$ component (lipoamide dehydrogenase) of the complex, but only in serum (Barbeau et al, 1976; Melançon et al. 1977). The present study was designed to investigate whether the lipoamide dehydrogenase (LAD) defect is present in other tissues of the body, and whether it was found in all patients with typical Friedreich's ataxia.

\section{SUBJECTS, MATERIALS AND METHODS}

$\mathrm{PDH}, \alpha-\mathrm{KGDH}$ activity in platelets, and LAD activity in platelets and serum were estimated in 11 patients with typical Friedreich's ataxia (Group Ia) and 10 agematched healthy controls (Geoffroy et al., 1976). In some cases, blood samples were not sufficient for all determinations, which accounts for differences in numbers of individuals reported. In a further study, serum LAD activity was compared in 10 diabetic patients and 4 normal controls.

Sodium $\left(1-{ }^{14} \mathrm{C}\right)$ pyruvate $(4.8 \mathrm{Ci} / \mathrm{mol})$ and sodium 2-keto $\left(1-1{ }^{14} \mathrm{C}\right)$ glutarate $(54.1 \mathrm{Ci} / \mathrm{mol})$ were purchased from New England Nuclear Corp. Non radioactive sodium 2-ketoglutarate, glycerol, nicotinamide, NAD (grade III yeast), thiamine pyrophosphate chloride, hyamine hydroxide and bovine serum albumine were obtained from Sigma Chemical Corp. Coenzyme A was bought from P.L Biochemicals Inc. Toluene "scintanalyzed grade", methanol "spectranalyzed" were from Fisher Scientific Co., and liquifluor from New England Nuclear. All other reagents were of analytical grade. DL-6,8-thioctic acid amide (DL-lipoamide) and NAD were purchased from Sigma Chemical Corp. Glycyl-glycine was obtained from ICN Pharmaceuticals Inc.

\section{Preparation of platelet} enriched fractions

Blood was obtained by venipuncture in fasting patients, using $20 \mathrm{ml}$ plastic syringe. Each syringe contained $1.5 \mathrm{ml}$ of a solution of $1 \%$ EDTA and $0.7 \% \mathrm{NaCl} ; 13.5 \mathrm{ml}$ of blood was taken by syringe. Three syringes were used for each patient. (At the same time $10 \mathrm{ml}$ of blood without anticoagulant were taken for serum LAD analysis). Blood was transferred immediately to centrifuge tubes and cooled on ice. Tubes were centrifuged $(120 \mathrm{G}, 15 \mathrm{~min}$, $4^{\circ} \mathrm{C}$ ) and platelet rich plasma was obtained. (All experimental steps using platelet rich plasma were carried out using siliconized pipettes and polypropilene tubes). Platelets were isolated by centrifugation $(20,000 \mathrm{G}, 5$ $\min , 4^{\circ} \mathrm{C}$ ). To lyse the contaminating red cells the pellet was resuspended in $3 \mathrm{ml}$ of water for 90 seconds and then $1 \mathrm{ml}$ of $0.6 \mathrm{mM} \mathrm{NaCl}$ was mixed rapidly.

The platelets were again collected by centrifugation $\left(20,000 \mathrm{G}, 5 \mathrm{~min}, 4^{\circ} \mathrm{C}\right)$. The pellets were then washed two times in an amount of buffered saline (0.0324 $\mathrm{M}$ phosphate buffer, $\mathrm{pH} 7.4,0,11 \mathrm{M} \mathrm{NaCl}$ for the detection of PDH and $\alpha-\mathrm{KGDH}$ activity and $0.5 \mathrm{M}$ glycyl glycine, $\mathrm{pH} 7.8,0,11 \mathrm{M} \mathrm{NaCl}$ for the $\mathrm{LAD}$ activity estimation) equal to $1 / 3$ the original volume of blood.

\section{$P D H, \alpha-K G D H$ assay}

PDH, $\alpha-K G D H$ assay was performed using modifications of the method described by Blass et al. (1977). $1.2 \mathrm{ml}$ of glycerolbuffer mixture (2 parts of glycerol and 3 parts of $0.0324 \mathrm{M}$ potassium phosphate buffer, $\mathrm{pH} 7.4$, 
containing $4 \mathrm{mM} \mathrm{MgCl}, 30 \mathrm{mM}$ nicotinamide, $1 \mathrm{mM} \mathrm{Na2SO} 3$ ) was added to the final pellet. The cells were then disrupted in $3 \mathrm{ml}$ glass homogenizer (Fisher Scientific Homogenizer, $1700 \mathrm{rpm}$ ) with teflon pestle in an ice bath. Protein detection was done according to the Lowry's technique (1951). The yield was about $0.07 \mathrm{mg}$ of protein per $\mathrm{ml}$ of blood.

In $15 \times 50 \mathrm{~mm}$ plastic tubes, in ice, were mixed $200 \mu \mathrm{l}$ of homogenate, $10 \mu \mathrm{l}$ of a solution containing COA, NAD, TPP $(2 \mathrm{mM}$ each) in $0.0324 \mathrm{M}$ potassium phosphate buffer, $\mathrm{pH} 7.4$ and $20 \mu$ lof a solution either $1.8 \mathrm{X}$ $10^{5} \mathrm{cpm}$ sodium $\left(1{ }^{-14} \mathrm{C}\right)$ pyruvate or $3.9 \times 10^{5}$ $\mathrm{cpm}$ sodium 2-keto $\left(1-{ }^{14} \mathrm{C}\right)$ glutarate and $1 \mathrm{mM}$ of non radioactive sodium 2-ketoglutarate, both in $0.0324 \mathrm{M}$ potassium phosphate buffer, $\mathrm{pH}$ 7.4. All assays were done in triplicate. Blanks were obtained by adding $0.1 \mathrm{ml}$ of 10 $\mathrm{N}_{2} \mathrm{SO}_{4}$ to the reaction mixtures.

Tubes were closed with rubber caps from which were suspended disposable plastic center wells (Kontes Glass, N.J.) containing filter paper wet by $0.2 \mathrm{ml}$ of $1 \mathrm{M}$ hyamine hydroxide in methanol. Then they were incubated for 30 minutes at $30^{\circ} \mathrm{C}$. After incubation, $0.1 \mathrm{ml} 10 \mathrm{~N} \mathrm{H}_{2} \mathrm{SO}_{4}$ was added to each tube; tubes were shaken for 30 minutes more. The wells were transferred to vials containing $10 \mathrm{ml}$ of liquifluor-methanol-toluene mixture $(12: 200: 400 \mathrm{v} / \mathrm{v} / \mathrm{v})$ and radioactivity was determined by liquid scintillation using a Packard model 3375 Tricarb liquid scintillation counter. Each sample was counted for $5 \mathrm{mi}-$ nutes. PDH and $\alpha-\mathrm{KGDH}$ activity was expressed in $\mathrm{p} \mathrm{mol} / \mathrm{min} / \mathrm{mg}$ prot.

\section{$L A D$ assay in platelets}

One $\mathrm{ml} 0.5 \mathrm{M}$ glycyl-glycine buffer, $\mathrm{pH} 7.8$, was added to each pellet and the platelets were disrupted by sonification ( 8 bursts for 15 seconds, power $30 \%$ of the maximum, Sonic 300 dismembrator, Artek Systems Corporation, Farmingale, N.Y.). Platelet lysates were centrifuged at $12,000 \mathrm{G}, 10$ minutes and the clear supernatant saved. Assays were performed with a ACTA M VI Beckman recording spectrophotometer with constant temperature cell holder equilibrated at $30^{\circ} \mathrm{C}$ accord- ing to the Pelley's technique (1976) with some modifications.

The assay mixture consisted of DL-6,8-thioctin acid amide $(7.8 \mathrm{mM})$, dithiotreitol $(14.7 \mathrm{mM}$, both dissolved together in $95 \%$ ethanol and $50 \mathrm{mM}$ glycyl-glycine buffer, $\mathrm{pH} 8.2,1: 3 \mathrm{v} / \mathrm{v}), \mathrm{NAD}^{+}(3.3 \mathrm{mM})$, platelet lysates $(25-66 \mu \mathrm{g}$ of cell protein as measured by the method of Lowry), glycyle-glycine buffer $(0.275 \mathrm{M}, \mathrm{pH} 7.8)$ made up to a total volume of $1.1 \mathrm{ml}$. The reduction of the NAD during the enzyme-catalyzed oxidation of lipoamide was measured spectrophotometrically at $340 \mathrm{nM}$. The assay was done in a cuvette with $1.0 \mathrm{~cm}$ light path. The values of LAD activity were expressed in $\mu$ $\mathrm{mol} / \mathrm{min} / \mathrm{mg}$ proteins.

\section{LAD assay in serum}

To estimate LAD activity in serum the same technique as for platelets was used.

\section{RESULTS}

The values of the activity of $\mathrm{PDH}$, $\alpha-\mathrm{KGDH}$ and LAD in platelets and of LAD in serum are shown in Table 1. Our results on the oxidation of pyruvic acid and $\alpha$-ketoglutaric acid by control platelets $(\mathrm{PDH}=188.3$ $+33 \mathrm{p} \mathrm{mol} / \mathrm{min} / \mathrm{mg}$ prot and $\alpha-\mathrm{KGDH}=495.3 \pm 80 \mathrm{p} \mathrm{mol} /$ $\mathrm{min} / \mathrm{mg}$ prot.) are close to the values reported by Blass et al. (1977) $(\mathrm{PDH}=169 \pm 9 \mathrm{p} \mathrm{mol} / \mathrm{min} / \mathrm{mg}$ prot. $\alpha-\mathrm{KGDH}=535 \pm 27 \mathrm{p} \mathrm{mol} / \mathrm{min} / \mathrm{mg}$ prot.), but the results for ataxic patients differed.

A decrease in the activity of $\mathrm{PDH}$ (16\%), $\alpha$-KGDH complex (19\%), LAD in platelets (15\%) and LAD in serum $(18 \%)$ was found in the ataxic patients, but only the last figure was statistically significiant. A slight cor-

TABLE 1 PDH, $\alpha$-KGDH AND LAD IN FRIEDREICH'S ATAXIA

(mean \pm S.E.)

MEASUREMENT

Platelet PDH

(p mol/min/mg prot.)

Platelet $\alpha-\mathrm{KGDH}$

(p mol/min/mg prot.)

Platelet LAD

( $\mu \mathrm{mol} / \mathrm{min} / \mathrm{mg}$ prot.)

Serum IAD

$\left(\begin{array}{c}\mu \mathrm{mol} / \mathrm{min} / \mathrm{mg} \text { prot. } \\ \times 10^{-4}\end{array}\right)$
N OONTROL SUBJECTS

\section{$\underline{N}$}

FRIEDREICH'S ATAXIA

\& CONTROLS

10

$188.3 \pm 33$

11

$157.8 \pm 31$

83.8

10

$495.3 \pm 80$

11

$402.4 \pm 76$

81.3

9

$0.16 \pm 0.01$

8

$0.13 \pm 0.01$

84.9

10

$1.84 \pm 0.12$

11

$1.50 \pm 0.06^{\star}$

81.8 relation was found between $\mathrm{PDH}$ and $\alpha-K G D H$ values in platelets of ataxic patients $(r=0.590)$, while no correlation was found between either PDH or $\alpha-K G D H$ and LAD either in platelets or in serum.

Finally, when LAD in serum was estimated in 10 diabetic patients and four controls, no significant differences appeared (Table 2).

\section{DISCUSSION}

Pyruvate oxidation is an extremely complex biochemical phenomenon which has been shown by Reed and Cox (1966) to comprise a successive cascade of at least three enzymatic steps under the regulatory control of two more enzymes. The first component of the pyruvate dehydrogenase (PDH) complex is pyruvate decarboxylase $\left(E_{1}\right)$, a thiamine pyrophosphate dependent enzyme. The second step ( $\left.E_{2}\right)$ is the enzyme lipoyl reductase transacetylase. The last step $\left(E_{3}\right)$ is dihydrolipoyl dehydrogenase, also called lipoamide dehydrogenase (LAD). The function of LAD is to regenerate oxidized lipoid acid.

Previous studies (Kark et al., 1977; Blass et al., 1977) have shown that, in some patients with spinocerebellar degenerations, there may be evidence of delayed pyruvate oxidation. Blass and his collaborators $(1976,1977)$ found decreased values of PDH in various tissues. The present study does not entirely confirm the above findings. We were unable to find statistically significant decreases in platelet PDH and $\alpha-\mathrm{KGDH}$ values when the Friedreich's ataxia patients were examined as a group. However, some patients and control subjects had values outside the normal control range. Thus, 5/11 ataxics had platelet PDH values below $120 \mathrm{p}$ $\mathrm{mole} / \mathrm{min} / \mathrm{mg}$ protein (range $0-101$ ) was well as $2 / 10$ of the control subjects (values 81 and 95)). Similarly, $6 / 11$ ataxics had platelet $\alpha-\mathrm{KGDH}$ values below $260 \mathrm{p} \mathrm{mole} / \mathrm{min} / \mathrm{mg}$ protein (range 167-245) as opposed to only one of the controls (value 219). This heterogeneity of a group of patients with ataxia was recently confirmed in platelets by Blass and his collaborators (1977). These au- 
thors studied 16 unselected patients with spinocerebellar degenerations and 8 controls. PDH activity in 8 of the patients was low (range 40-93) while it was normal in the other 8 (range 122-182). Their control patients had platelet PDH activity values of $171+14 \mathrm{p} \mathrm{mole} / \mathrm{min} / \mathrm{mg}$ protein (range 120-231).

Unfortunately, the clinical criteria of diagnosis used by Blass and his co-authors (1976, 1977) are not as strict as the ones we used to define cases of "typical, type Ia, Friedreich's ataxia" (see Geoffroy et al., 1976). Many of their cases are not Friedreich's ataxia, but other forms of spinocerebellar degenerations. For example, many cases had increased osteotendinous reflexes and no cardiomyopathy, items which would have excluded them from our classification of typical Friedreich's ataxia. Therefore, it is difficult to compare our two groups. All we can agree on is that some patients with Friedreich's ataxia, but not all, show evidence of low PDH activity in platelets. This is not, however, a characteristic of the disease nor is it specific.

The same dilemma applies to lipoamide dehydrogenase activity determinations. In previous studies (Barbeau et al., 1976; Melançon et al., 1977) we found a $29-47 \%$ decrease in the activity of serum LAD. LAD values under the lower control figure of $2.25 \mathrm{KU} / \mathrm{L}$ were observed in 9 of the 18 patients. In the present study, as seen in Table 1, ataxic patients had platelet LAD values equal to $85 \%$ of control subjects (not significantly different), but serum values which were significantly reduced in the same patients. This again raises the possibility that the LAD defect, if it exists, is not present in all tissues, but is manifested in the serum as a result of a secondary defect caused in the huge muscle mass by neuropathic changes. Alternatively, two sub-populations of Friedreich's ataxia should be delineated and may be genetically determined. The first possibility was raised by recent experiments carried out but Butterworth et al. (1977) showing that muscle PDH activity is decreased only in experimental ani- mals made ataxic by the use of the polyneuropathy-producing substance acrylamide, but not in animals made ataxic from the cerebellar damage induced by 3-acetyl pyridine.

We have seen that the regenerative component ( $\left.E_{3}-L A D\right)$ is the only common denominator between pyruvate dehydrogenase and $\alpha$-ketoglutarate dehydrogenase and that it appears to be partially impaired in a sub-group of patients with Friedreich's ataxia, a sub-group which seems to have been specifically selected for by Blass et al. (1976) when they used muscle PDH activities as their criteria for study. We do not believe that the LAD defect observed, mainly in the serum, in patients with Friedreich's ataxia is the primary genetic deficiency in that disease. Our evidence would favor a regulatory defect, the nature of which is still unclear. The arguments for regulation by many hormonal, ionic and metabolic factors at various sites of the PDH complex is overwhelming (Reed and Cox, 1966). If the regenerating component of the complex is impaired alone, without the $E_{1}$ and $E_{2}$ components being altered, it would explain that the deficiency in pyruvate oxidation would appear only under conditions of metabolic stress, i.e. a glucose load (Barbeau et al., 1976). It should be made worse by the added presence of the metabolic changes inherent to diabetes (low insulin, high free fatty acids). However, (Table 2) in the present study we could not show any significant decrease in serum LAD activity in active diabetes. In conclusion, the serum LAD deficiency in
Friedreich's ataxia is probably secondary to a regulatory and not a genetic defect and possibly reflects changes in the muscle components secondary to the neuropathy of that disease.

\section{ACKNOWLEDGMENTS}

The authors would like to thank Mrs. Thérèse Cloutier, RT for technical assisatnce and Miss Danielle Bédard, RN for help with the patients. These studies were made possible through grants from La Fondation Jeanne Mance de l'Hôtel-Dieu, I'Association Canadienne de l'Ataxie de Friedreich and the Medical Research Council of Canada. Thanks are due to Miss Suzanne 'Gariépy for typing the manuscript. Dr. Filla was a recipient of a Canada Council Fellowship.

\section{REFERENCES}

BARBEAU, A., BUTTERWORTH, R. F., BRETON, G., MELANCCON, S., SHAPCOTT, D., GEOFFROY, G. and LEMIEUX, B. (1976), Pyruvate Metabolism in Friedreich's ataxia. Can. J. Neurol. Sci., 3, 379-388.

BLASS, J. P., CEDERBAUM, S. D. and KARK, R. A. P. (1977). Rapid diagnosis of pyruvate and ketoglutarate dehydrogenase deficiencies in platelet-enriched preparation from blood. Clin. Chim. Acta, 75, 21-30.

BLASS, J. P., KARK, R. A. P. and MENON, N. K. (1976). Low activities of the pyruvate and oxoglutarate dehydrogenase complexes in five patients with Friedreich's ataxia. New Engl. J. Med., 295, 62-67.

BLASS, J. P., KARK, R. A. P. and RODRIGUEZ-BUDELLI, M. (1977). Pyruvate dehydrogenase deficiency in spinocerebellar degenerations. Clin. Res., 25, 321A.

BUTTERWORTH, R. F., IZUMI, K., LANDREVILLE, $F$. and BARBEAU, $A$. (1977). Dosage de la pyruvate déshydrogénase musculaire dans deux modèles expérimentaux d'ataxie. Union Méd. Can., 106, 468-471.

GEOFFROY, G., BARBEAU, A., BRETON, G., LEMIEUX, B., AUBE, M.,

\section{TABLE 2 SERUM LIPOAMIDE DIHHYRUGEIIASE IN DIABETIC PATIENTS}

$$
\text { (mean } \pm \text { S.E.) }
$$

GROUP

Age-matched control subjects

Diabetic subjects (no

ataxia or polyneuropathy)
$\underline{\mathrm{N}}$

$\left(\mu \mathrm{mol} / \mathrm{min} / \mathrm{ing}\right.$ protein $\left.\times 10^{-4}\right)$

4

9
$2.08 \pm 0.15$

$2.20 \pm 0.13$ 
LEGER, C. and BOUCHARD, J. P. (1976). Clinical description and roentgenologic evaluation of patients with Friedreich's ataxia. Can. J. Neurol. Sci., 3, 279-286.

KARK, R. A. P., BLASS, J. P. and ENGEL, W. K. (1974). Pyruvate oxidation in neuromuscular diseases - Evidence of a genetic defect in two families with the clini- cal syndrome of Friedreich's ataxia. Neurology, 24, 964-971.

LOWRY, O. H., ROSEBROUGH, N. J., FARR, A. L. and RANDALL, R. J. (1951). Protein measurement with the folin phenol reagent. J. Biol. Chem., 93, 265-275.

MELANÇON, S. B., POTIER, M., DALLAIRE, L., GEOFFROY, G., LEMIEUX, B. and BARBEAU, A. (1977). Serum lipoamide dehydrogenase in Friedreich's ataxia. Pediat. Res., 11, 460.

PELLEY, J. W., LITTLE, G. H., LINN, T. C. and HALL, F. F. (1976). Lipoamide dehydrogenase in serum; a preliminary report. Clin. Chem., 22/2, 275-277.

REED, L. H. and COX, D. J. (1966). Macromolecular organization of enzyme systems. Ann. Rev. Biochem., 35, 57-84. 